\title{
Productivity Shocks And Real Exchange Rates In The Long-Run: Evidence For The G3 And EU Economies
}

Ordean Olson, (E-mail: olson@nova.edu), Nova Southeastern University

\begin{abstract}
This paper analyses the relationship between productivity and real exchange rates in Japan, United States, Germany and the European Union. Prior studies have revealed that productivity shocks have a minimum effect on real exchange rate fluctuations. This paper shows that productivity shocks account for most of the long-run fluctuations in the real exchange rates when long-run equilibrium relationships of the fundamental variables are considered. This would support empirical support of the Balassa Samuelson model where the main sources of long-run deviations for purchasing power parity are the differences in relative productivity.
\end{abstract}

\section{INTRODUCTION}

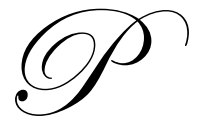

rior studies have reached a conclusion that the main sources of real exchange rate fluctuations are the result of real demand shocks in the short-run as well as the long-run Clarida and Gali (1994), Weber (1997), and Clarida and Evans (1995). Rogers (1999) and Eichenbaum and Evans (1995) argue the importance of monetary shocks. All of these studies concluded that productivity shocks have a negligible effect on real exchange rates. However, Canzoneri et al. (1999), Chinn and Johnson (1996) with versions of the Balassa Samuelson model reveal that relative productivity dominate their models.

The recent literature has often focused on total factor productivity (TFP), which assesses the relative importance of supply shocks (approximated by TFP) and demand shocks (approximated by government expenditures, etc.) in explaining movements in real exchange rates. Instead, we follow Hsieh (1982), and Marston (1987) and use the average products of labor to approximate supply shocks. We allow both supply and demand shocks to affect the exchange rates in the model. We make this choice for three reasons. First, we do not need data on sectoral capital stocks, which are likely to be less reliable than data on sectoral employment and value added. Second, we have shown that our development of the Balassa-Samuelson hypothesis holds for a broader class of technologies than the Cobb-Douglas production function, which is used to compute Solow residuals. Finally, our specification allows a more focused test of the first component of the Balassa-Samuelson hypothesis, which assumes that the relative price of non-tradable goods is proportional to the ratio of average labor products. The second component is the assumption of the PPP for traded goods.

Recent variance decomposition literature reveals studies that only model the changes in real exchange rates and fundamental variables. The long-term relationships between the variables were either rejected by Clarida and Gali (1999) or not covered in Weber (1997). Again, most studies do not find long-run equilibrium relationships between real exchange rates and various fundamental variables. However, there is some documentation of cointegration between levels of relative productivity and certain exchange rates MacDonald (1998).

This paper will first of all confirm the presence of cointegration and then show that relative productivity shocks represent the greatest part of the long-run variance decomposition of real exchange rates when long-run equilibrium relationships are considered. 


\section{METHODOLOGY}

Many models using only differenced data are misspecified and do not fully utilize the information available in the data. Also, the absence of cointegration may imply that it is not possible to construct a model that relates time varying equilibrium level of exchange rates to fundamental variables. However, the VAR models of Clarida and Gali (1994) allow for the identification of structural shocks, obtain variance decomposition and employ long-run equilibrium relationships between fundamental variables even though the long-run relationship with relative productivity was rejected. Following this model and the model of King et.al. (1991), we employ a cointegrated VAR model and identify structural shocks by imposing long-run restrictions on these effects as shown in equation 1.

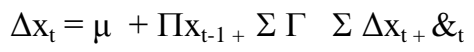

This can be shown as a common trends model following Stock and Watson (1993) as follows:

$\mathrm{x}_{\mathrm{t}}=\mathrm{x}_{0}+\mathrm{A}+\mathrm{Ar}_{\mathrm{t}}+\varnothing(\mathrm{L}) \mathrm{v}_{\mathrm{t}}$

where

$r_{t}=\mu+r_{t-1}+\Phi_{t}$

The number of independent stochastic trends $\mathrm{k}$ in the common trends model (2) is determined by the number of cointegrating vectors $r$ in equation (1). $K=n-r r_{t}$ are the stochastic trends. The drifts are represented by $\Phi_{t}$. The stochastic trends (long-run) affect on the variables $x_{t}$ are determined by the loading matrix $A$. The restrictions consist of $\mathrm{k}(\mathrm{k}-1) / 2$, which are imposed on the impact matrix A.

\section{Empirical Results}

Using equations 1-3 we estimate the common trends model. This is done for each bilateral real exchange rate and the corresponding time-series on relative government spending, relative real output and relative price levels. We construct bilateral real exchange rates between the United States, Japan, Germany and the European Union from nominal exchange rates and relative price levels (CPI). The data for this study was collected from the OECD database Main Economic Indicators. The sample period is from 1970 to 2005.

Even though the tests that we consider focus on the long-run behavior of the relative prices, relative productivities and nominal exchange rates, we will examine both the short-run and the long-run behavior of each of the series.

In order to determine whether each of the series has stationary deviations from a determined trend we carry out augmented Dickey-Fuller (1979) unit root tests. If the data contain stochastic trends, the Basassa-Samuelson model implies that pairs of series must share the same stochastic trend. That is, they must be cointegrated. For each country, we test for cointegration using standard residual-based tests. We test the null hypothesis that the estimated residuals have a unit root as suggested by Engle and Granger (1987) and Phillips and Ouliaris (1990).

Before examining this hypothesis, we examine the trend behavior of each series, and find that there is evidence against the null hypothesis of a unit root in relative productivities, relative prices of goods, and nominal exchanges rates. Table 1 contains the results of the test of the null hypothesis that relative prices of goods and relative productivities are not cointegrated. The ADF- type tests reject the null hypothesis of no cointegration for 1 country at the $5 \%$ level, and 2 of the test statistics are significant at the $10 \%$ level. The tests provide strong evidence that relative prices and relative productivities are, in fact, cointegrated. We conclude form Table 1 that the relative prices of traded goods and relative productivities of the traded goods are cointegrated as the BalassaSauelson model predicts. The ADF unit root test (available but not reported) indicates that the time series are I(1). 


\section{COINTEGRATION AND IDENTIFICATION}

The cointegration tests of Johansen (1988) indicate that there is one cointegrating vector in all of the cases. The issue of cointegration between real exchange rates and fundamental variables is controversial. However, tests for cointegration by Stock and Watson (1988) and Park (1992) also indicate that there is cointegration in each of the bilateral systems employed in this study. We find that when estimating cointegrating vectors, countries with high relative real GDP and high relative government consumption have stronger real exchange rates in the long-run (Table 1).

Given that there is one cointegrating vector and three variables, there are three stochastic trends. They are identified as a relative productivity shock, a government spending shock, and a monetary shock. All of the three shocks are employed to affect the real exchange rate and the relative price level in the long-run. Monetary shocks are assumed to not affect relative output or government spending in the long-run. Also, government spending shocks are allowed to affect output as we assume that changes in productivity do not affect government spending in the long-run following the model of Rogers (1999). Identifying structural shocks with VAR'S has been questioned by Faust and Leeper (1997). However, several empirical studies have confirmed that VAR models identify productivity shocks that closely resemble classic residuals Kiley (1998) and Alexius and Carlsson (2002). Figure 1 shows that the stochastic relative productivity trends closely tract relative real GDP. The short-run responses of output to productivity shocks and government spending shocks show the expected relationships in the model. Most of these impulse- response-functions are not significant. All three real exchange rates increase greatly in response to increases in productivity shocks in the long-run. Again, this is consistent with the Balassa (1964) and Samuelson (1964) approach but not with models without a distinction between tradable and non-tradable goods (Odstfeld (1985).

\section{VARIANCE DECOMPOSITION}

The results of the forecast error variance decompositions of the three real exchange rates over a time period of 10 years are shown in Table 2. Demand shocks provide the biggest percentage of the short-run movements accounting for more than $50 \%$ of the forecast error variance in the first 5 years ( 3 years in the USD/JPY exchange rate). The relative importance of demand shocks then declines as the time period is extended. At the 10 time period, demand shocks account for only $26 \%$ of the variance of the USD/JPY exchange rate, $44 \%$ for the USD/DEM exchange rate and $46 \%$ for the GBP/USD exchange rate. The remaining variance at the 10 year period of the three exchange rates can be explained by the changes in the other fundamental variables. Monetary shocks represent only about 4-8 \% of the total variances and they are fairly constant over the 10-year period. Government spending shocks are negligible with the USD/JPY and the GBP/USD exchange rates but show a higher percentage of $7 \%$ in the USD/DEM exchange rate. The impact of productivity shocks increases continuously over the 10 -year time period increasing from $20 \%$ of the forecast error variance of the first year to about $50 \%$ at the 10 -year period. The results of this study show the increasing importance of productivity over the 10 -year period. Figure 2 shows the impact of productivity shocks on the USD/DEM, USD/JPY and the GBP/USD exchange rates. The long-run forecast error variance decompositions shown in Table 2 reveal what structural shocks have caused the main movements in the real exchange rates. Productivity shocks account for $47-63 \%$ of the long-term variances of the USD/JPY and the GBP/USD exchange rates while the percentage is lower for the USD/DEM exchange rate at 28\%. The results of this study clearly contradict many previous studies that show supply shocks as accounting for a small percentage of the movements of exchange rates. The highest previously documented percentage for major currencies was $33 \%$ of the forecast error variance Weber (1997).

This study revealed that government spending accounted for 1-7\% of the long-run movements. They were more important in the USD/DEM exchange rate (7\%) and less important in the USD/JPY and the GBP/USD exchange rates $(0 \%$ and $1 \%)$. The influence of monetary shocks was higher for the USD/DEM exchange rate (7\%), $\mathrm{USD} / \mathrm{JPY}(8 \%)$ and less for the GBP/USD exchange rates (4\%). 


\section{IMPULSE RESPONSES}

Figure 3 displays the impulse responses of the real exchange rate to the various one-standard deviation shocks. The results closely resemble those of Clarida and Galf (1992). Also note that our results are fairly consistent across countries and relatively robust, even if some individual impulse responses occasionally fail the 5\% significance tests. The major impulse response of real exchange rates is found with respect to aggregate demand shock.. For all three exchange rates these shocks have a highly significant impact over the 10 -year time periods, and the correlation between these impulse responses is high. Money supply shocks have only short-run real exchange rate effects, which tend to become insignificant after 2 year time periods. Productivity shocks have a very significant long-run impact on the USD/JPY, USD/DEM and the GBP/USD exchange rates. Finally, government disturbances have a minimum impact and are insignificant. This suggests the fundamental real factors are significant in the long-run fluctuations in real exchange rates.

\section{CONCLUSIONS}

Previous studies of the influence of productivity shocks to the fluctuations of real exchange rates conclude that the impact is negligible. This study takes into account the long-run equilibrium relationships between exchange rates and fundamental variables using a statistical model. The study reveals relative productivity shocks are found to be a major source of the long-run movements in real exchange rates. For the USD/JPY exchange rate 61-64 \% of the permanent movements are due to productivity shocks. For the GBP/USD and the USD/DEM exchange rates the percentages are $47 \%$ and $28 \%$, respectively. The real effects of money are fairly constant over the 10 year period and account for $8 \%$ or less of the forecast error variance.

\section{REFERENCES}

1. Alexius, A., and Carlsson, M., Measures of Technology and the Business Cycle, Review of Economics and Statistics 87.

2. Balassa, B., The Purchasing Power Parity: A Reapproval, Journal of Political Economy 72 (1964), pp. 584-596.

3. Canzoneri, M., and Diba, B., Relative Labor Productivity and the Real Exchange Rate in the Long-run: Evidence for a Panel of OECD Countries, Journal of International Economics 47 (1999), pp. 245-266.

4. Chinn, M., and Johnson, L., 1996, Real Exchange Rate Levels, Productivity and Demand Shocks: Evidence from a Panel of 14 Countries, NBER Working Paper No. 5709.

5. Clarida, R., and Gali, J., Sources of Real Exchange Rate Fluctuations: How Important Are Nominal Shocks? Carnegie Rochester Series on Public Policy 41 (1994).

6. Eichenbaum, M., and Evans, C., Some Empirical Evidence of the Effects of Shocks to Monetary Policy on Exchange Rates, Quarterly Journal of Economics 110 (1995), pp. 975-1010.

7. Faust, J., and Leeper, E.,When Do Long-run Identifying Restrictions Give Reliable Results? Journal of Business and Economics 15 (1997), pp. 345-353.

8. Johassen, S., Statistical Analysis of Cointegrating Vectors, Journal of Economic Dynamics and Control 12 (1988), PP.231-254.

9. Kiley, M., Labor Productivity in U.S. Manufacturing: Does Sectoral Movements Reflect Technology Shocks? Mimeo, Federal Reserve Board (1998).

10. King, R., and Plosser, J., and Stock, J., and Watson, M., Stochastic Trends and Economic Fluctuations, American Economic Review 81 (1991), pp.819-840.

11. MacDonald, R., What Do We Really Know About Real-Exchange Rates? Working Paper No. 28. Oesterreich Nationalbank.

12. Obstfeld, M., Floating Exchange Rates: Experience and Prospects, Brookings Papers on Economic Activity 2 (1985), pp.369-450.

13. Park, J. Cannonical Cointegrating Regressions, Econometrica 60 (1992), pp.119-143.

14. Rogers, J., Monetary Shocks and Real Exchange Rates, Journal of International Economics 49, (1999), pp.269-288. 
15. Samuelson, P., Theoretical Notes on Trade Problems, Review of Economics and Statistics 46 (1964), pp.145-154.

16. Stock, J and Watson, M., A Simple Estimator of Cointegrating Vectors In Higher Order Integrated Systems, Econometrica 61 (1993), pp. 783-820.

17. Weber, A., Sources of Purchasing Power Disparities Between the G-3 Economies, Journal of the Japanese and International Economies 11 (1997), pp. 548-583.

\section{APPENDIX}

Table 1: Cointegration Test Statistics for the Key Variables in the Bilateral Relationships Between the G3 Countries

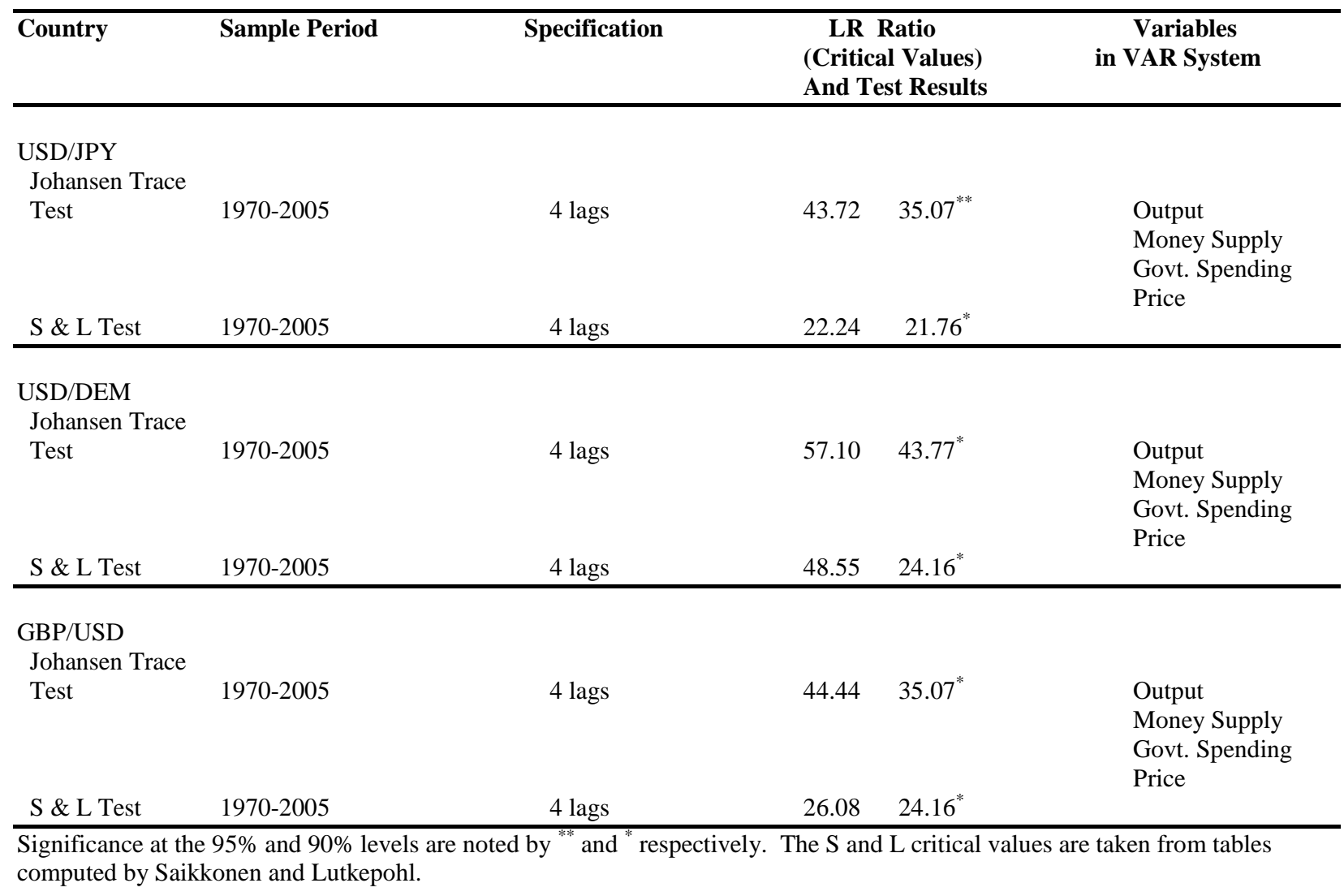


Table 2: Forecast Error Variance Decomposition at One to 10 Years

\begin{tabular}{|c|c|c|c|c|c|c|}
\hline Currency & Time & Prod. & Output & Govt. & Money Supply & Aggregate Demand \\
\hline USD/JPY & $\begin{array}{l}1 \\
2 \\
3 \\
4 \\
5 \\
6 \\
7 \\
8 \\
9 \\
10 \\
\end{array}$ & $\begin{array}{l}5 \\
4 \\
38 \\
53 \\
59 \\
61 \\
61 \\
62 \\
62 \\
63 \\
\end{array}$ & $\begin{array}{l}1 \\
1 \\
3 \\
2 \\
2 \\
2 \\
2 \\
2 \\
3 \\
3 \\
\end{array}$ & $\begin{array}{l}1 \\
9 \\
8 \\
5 \\
3 \\
1 \\
1 \\
1 \\
0 \\
0 \\
\end{array}$ & $\begin{array}{l}9 \\
4 \\
7 \\
7 \\
7 \\
8 \\
8 \\
8 \\
8 \\
8 \\
\end{array}$ & $\begin{array}{l}85 \\
82 \\
50 \\
33 \\
29 \\
28 \\
28 \\
27 \\
27 \\
26 \\
\end{array}$ \\
\hline USD/DEM & $\begin{array}{l}1 \\
2 \\
3 \\
4 \\
5 \\
6 \\
7 \\
8 \\
9 \\
10\end{array}$ & $\begin{array}{l}18 \\
22 \\
24 \\
26 \\
26 \\
27 \\
28 \\
28 \\
29 \\
28\end{array}$ & $\begin{array}{l}20 \\
19 \\
18 \\
17 \\
16 \\
15 \\
15 \\
14 \\
14 \\
14\end{array}$ & $\begin{array}{l}1 \\
1 \\
1 \\
2 \\
3 \\
4 \\
5 \\
6 \\
6 \\
7\end{array}$ & $\begin{array}{l}1 \\
2 \\
2 \\
2 \\
1 \\
2 \\
3 \\
5 \\
6 \\
7\end{array}$ & $\begin{array}{l}60 \\
56 \\
55 \\
53 \\
54 \\
52 \\
49 \\
47 \\
47 \\
44\end{array}$ \\
\hline GBP/USD & $\begin{array}{l}1 \\
2 \\
3 \\
4 \\
5 \\
6 \\
7 \\
8 \\
9 \\
10\end{array}$ & $\begin{array}{l}24 \\
26 \\
32 \\
38 \\
40 \\
43 \\
45 \\
46 \\
46 \\
47\end{array}$ & $\begin{array}{l}1 \\
1 \\
1 \\
1 \\
2 \\
2 \\
2 \\
2 \\
2 \\
2\end{array}$ & $\begin{array}{l}1 \\
1 \\
1 \\
1 \\
1 \\
1 \\
1 \\
1 \\
1 \\
1\end{array}$ & $\begin{array}{l}1 \\
1 \\
1 \\
1 \\
1 \\
1 \\
1 \\
1 \\
2 \\
4\end{array}$ & $\begin{array}{l}73 \\
71 \\
65 \\
59 \\
56 \\
53 \\
51 \\
50 \\
49 \\
46\end{array}$ \\
\hline
\end{tabular}


Figure 1

(a) Relative productivity trend and relative real GDP for the U.S. versus Japan; (b) relative productivity trend and relative real GDP for the U.S. versus Germany; (c) ) relative productivity trend and relative real GDP for the U.S. versus the U.K.
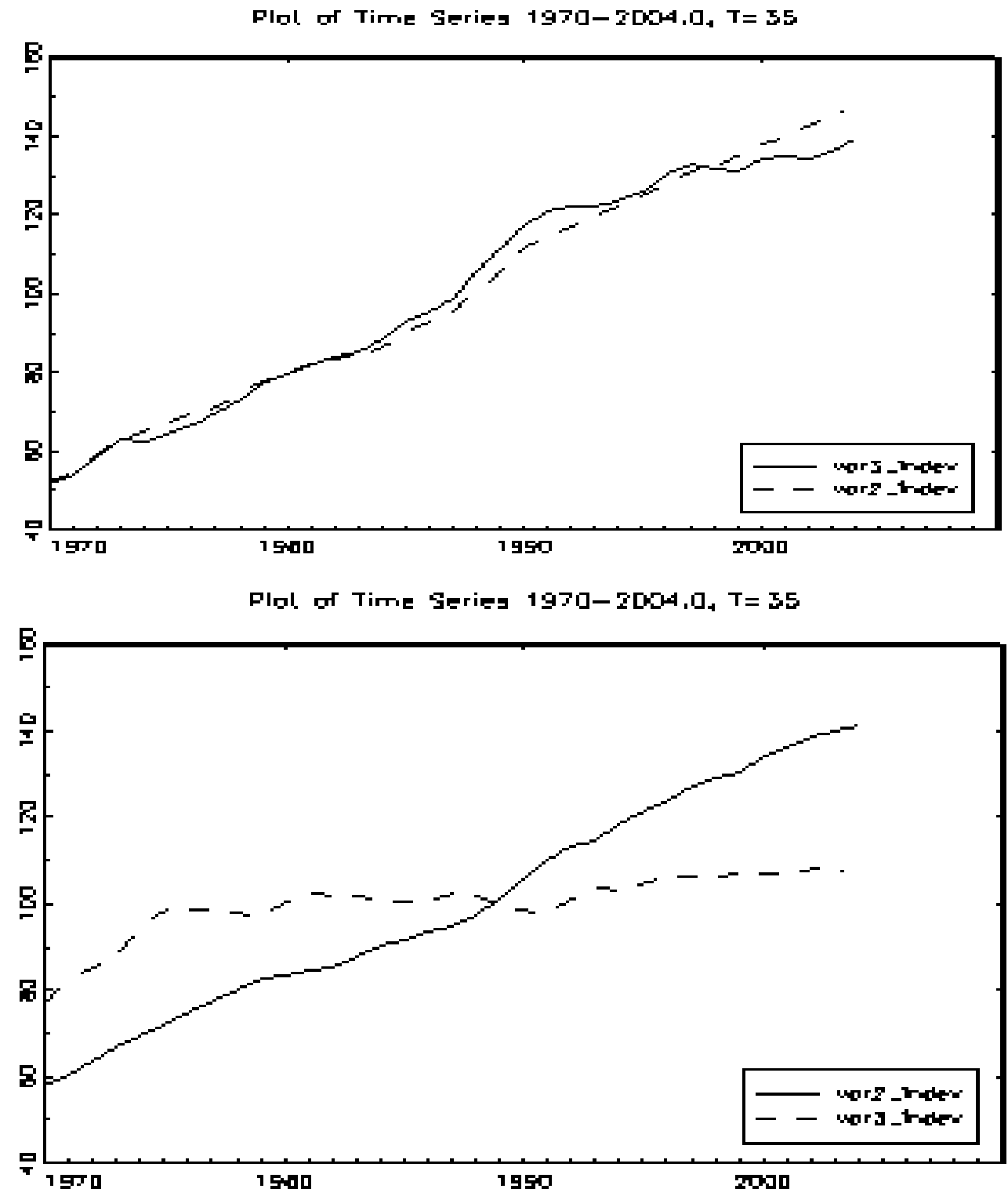
Flal or Time Gerieg 1970-7005.0, T=5B

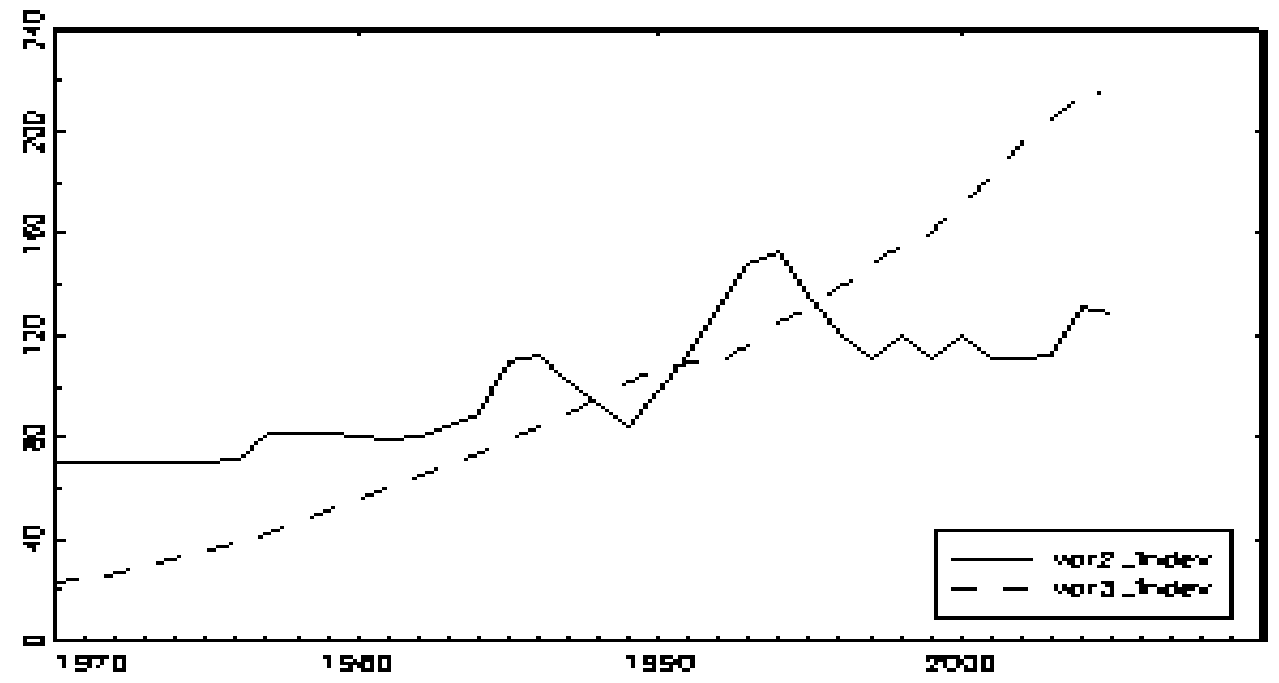

Figure 2

(a) The real exchange rate and its productivity driven part for the US versus the Germany; (b) the real exchange rate and its productivity driven part for the US versus Japan; (c) the real exchange rate and its productivity driven part for the US versus the UK.

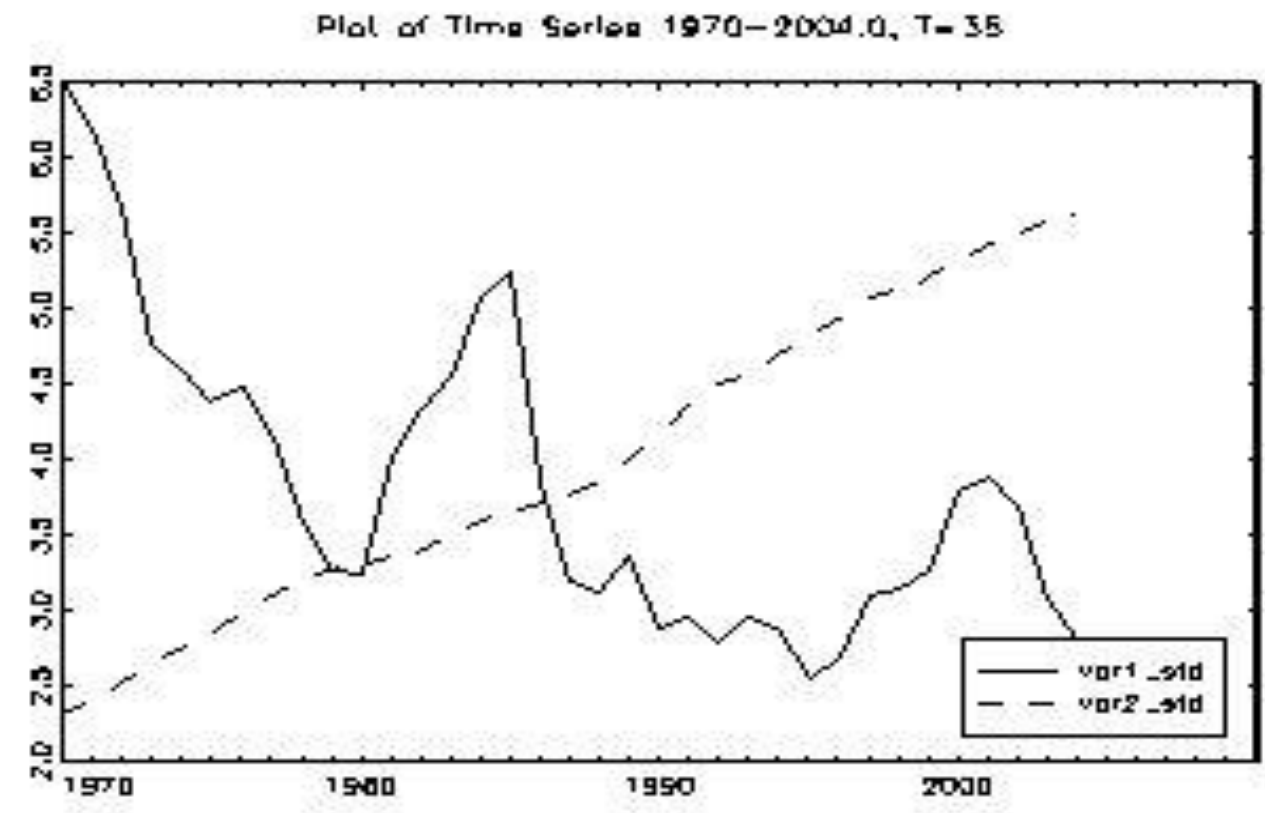


Dlol or Time Serieg 1970-200d.0, T= 35

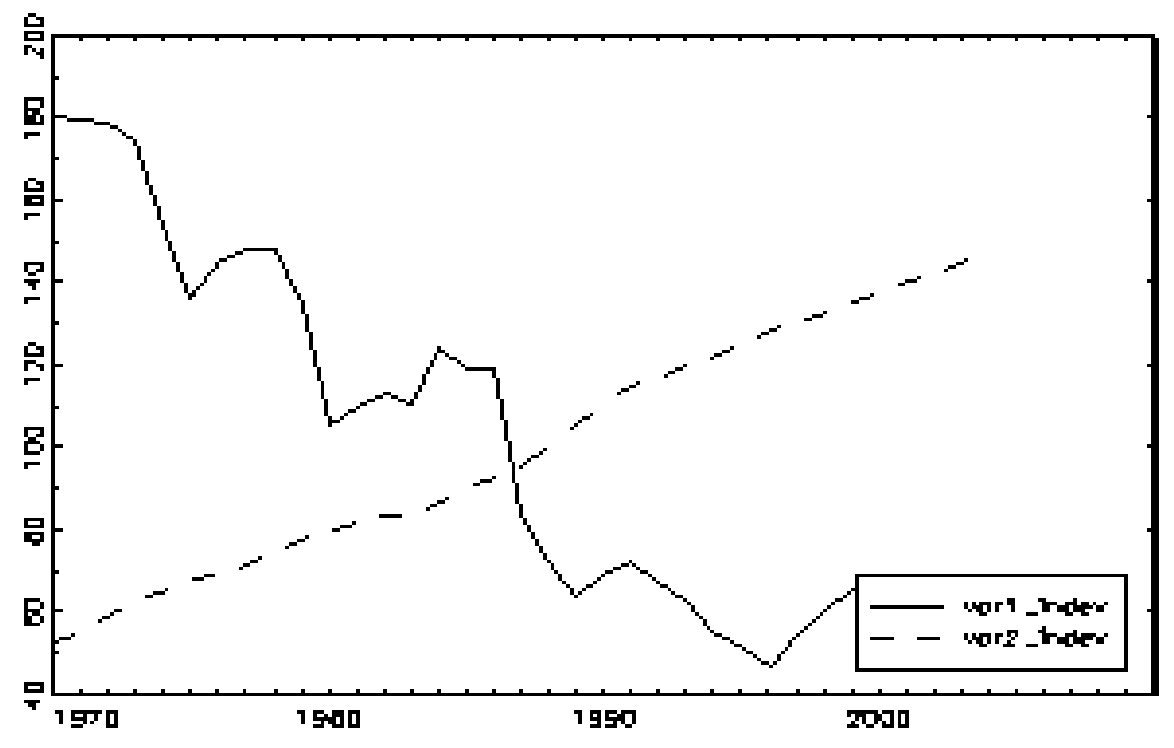

Plol or Time Serieg 1970-2004.0, T= 35

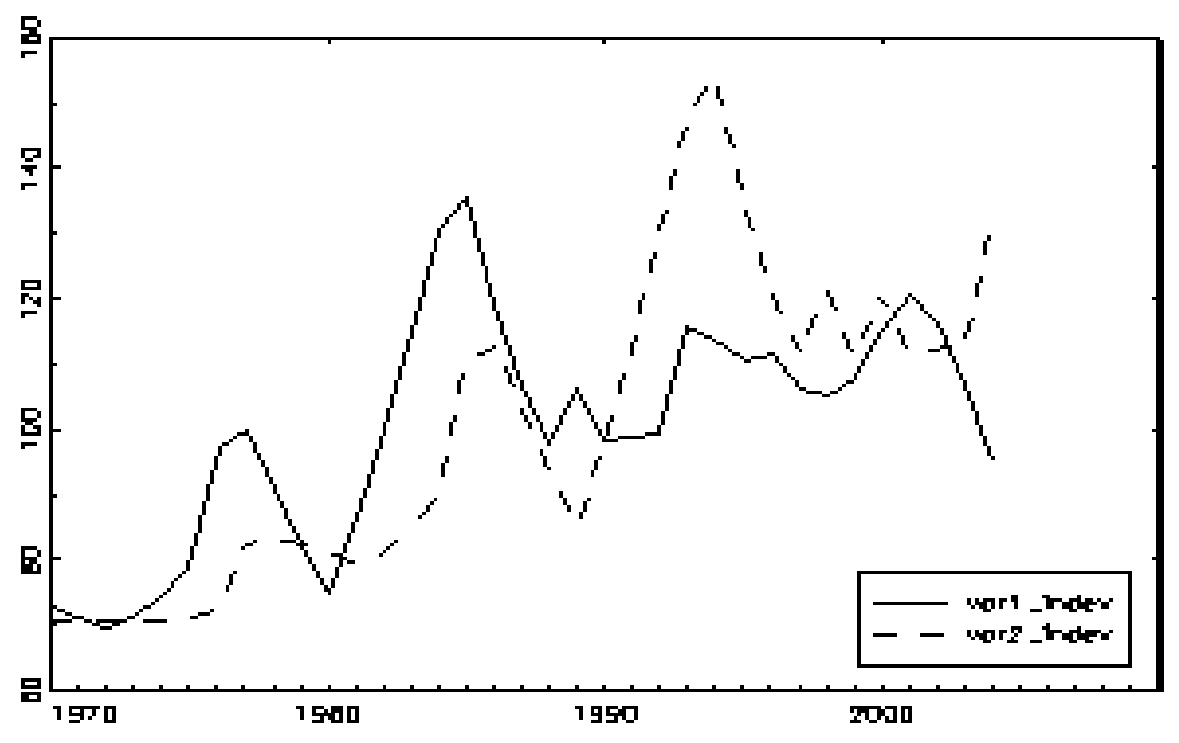


Figure 3

Impulse Responses for the USD/JPY Real Exchange Rates. The following variables are shown in the above graphs: Variable 1- real exchange rate, Variable 2- productivity, Variable 3- output.

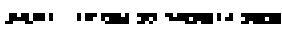

VAR Forecost Error Impulge Regponseg

vor $2->$ var 1

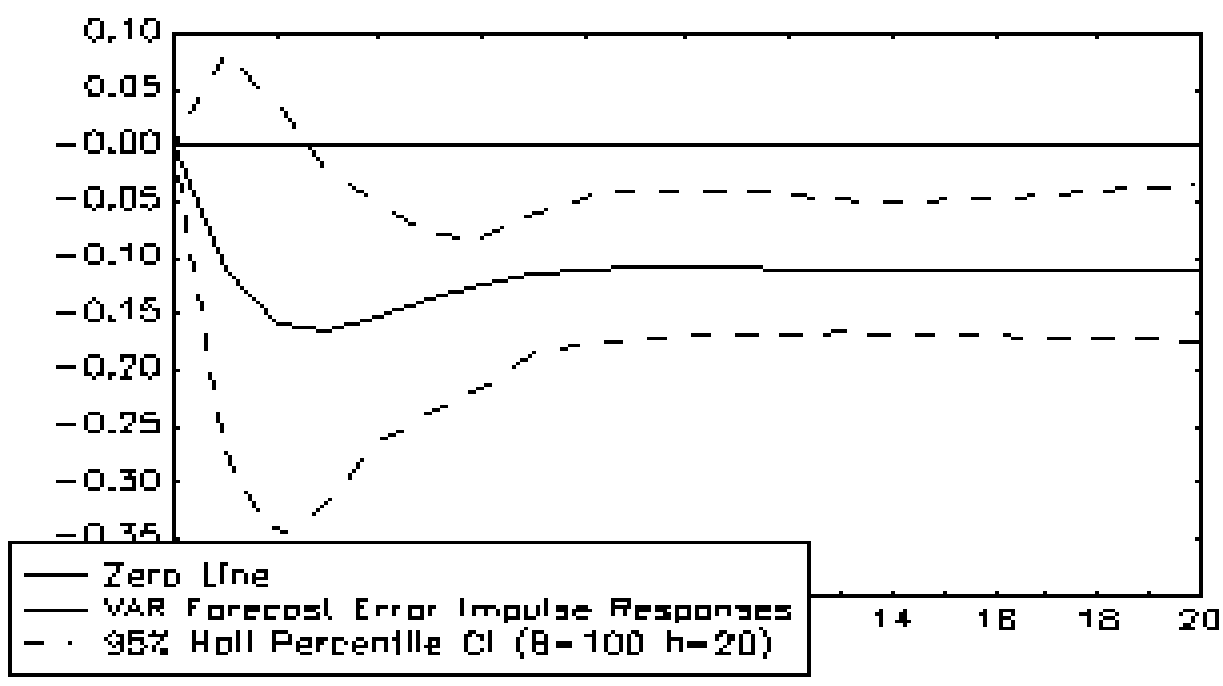

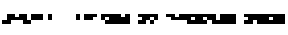

'uAF Forecost Error Impulge Regpongeg

or

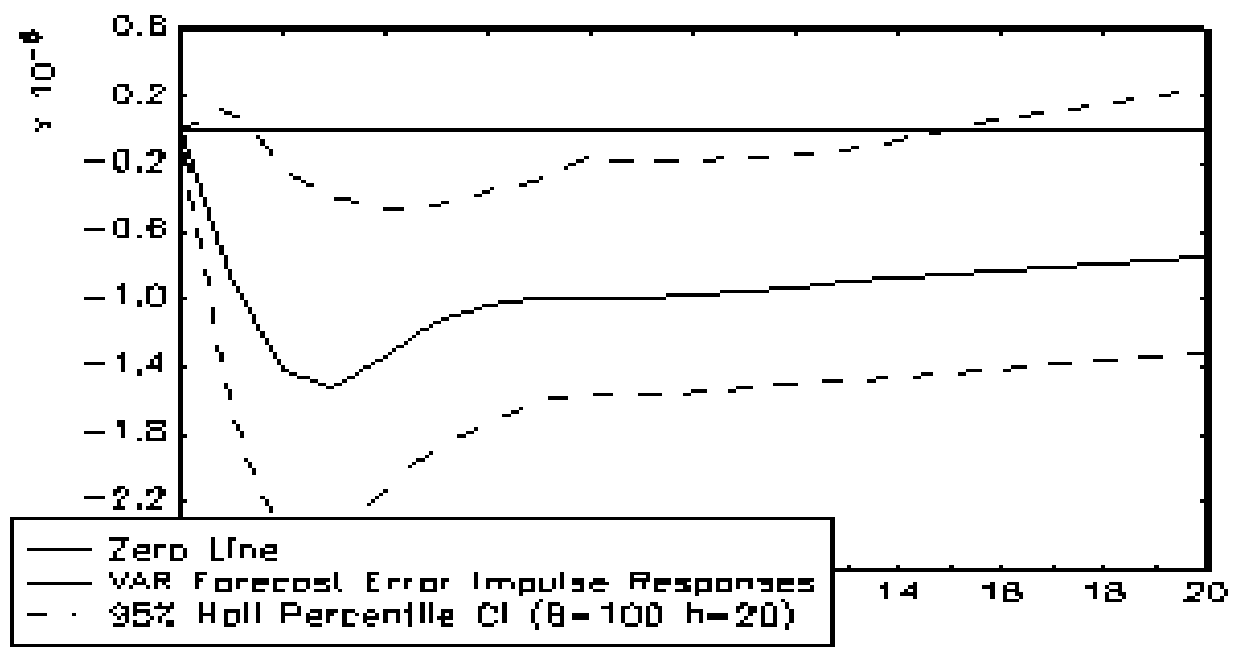




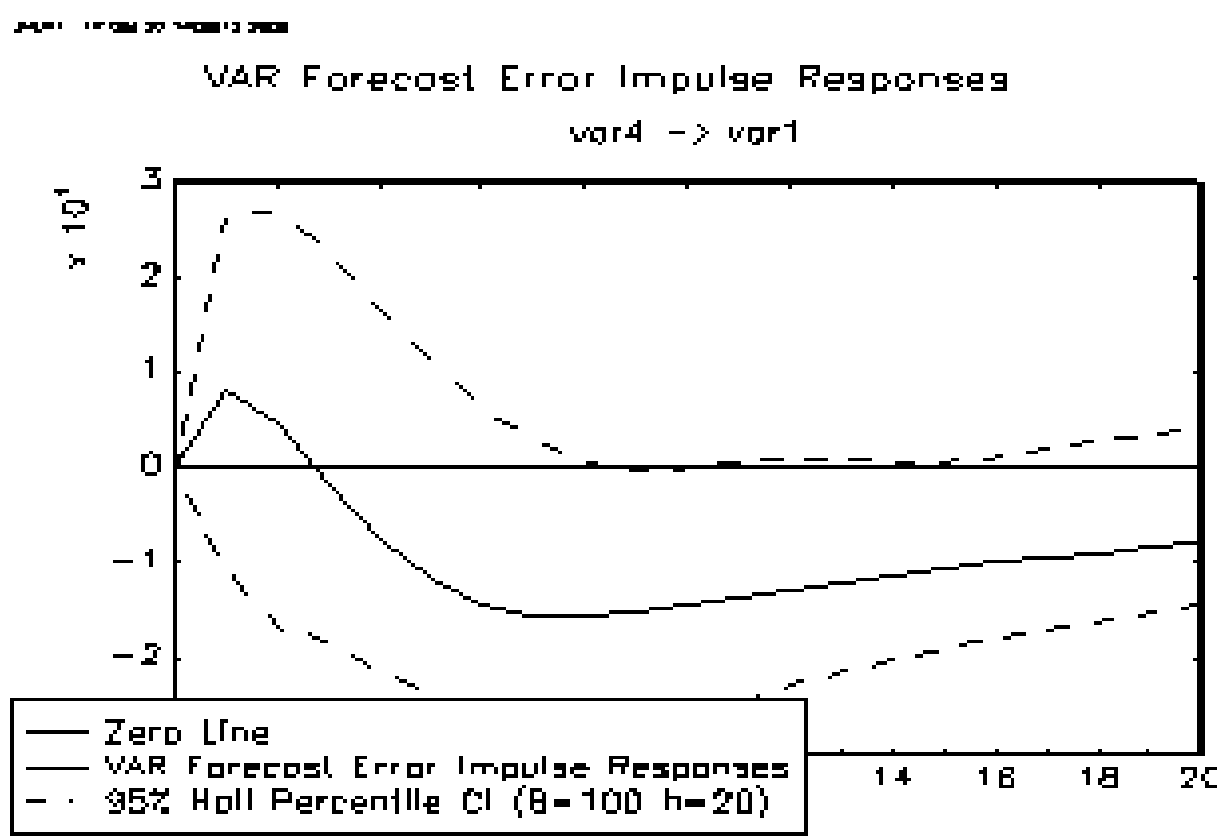

Figure 3

Impulse Responses for the USD/JPY Real Exchange Rates. The following variables are shown in the above graphs: Variable 1- real exchange rate, Variable 5- prices, and Variable 6- aggregate demand.

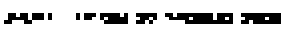

WAR Forecost Error Impulge Regpongeg

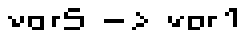

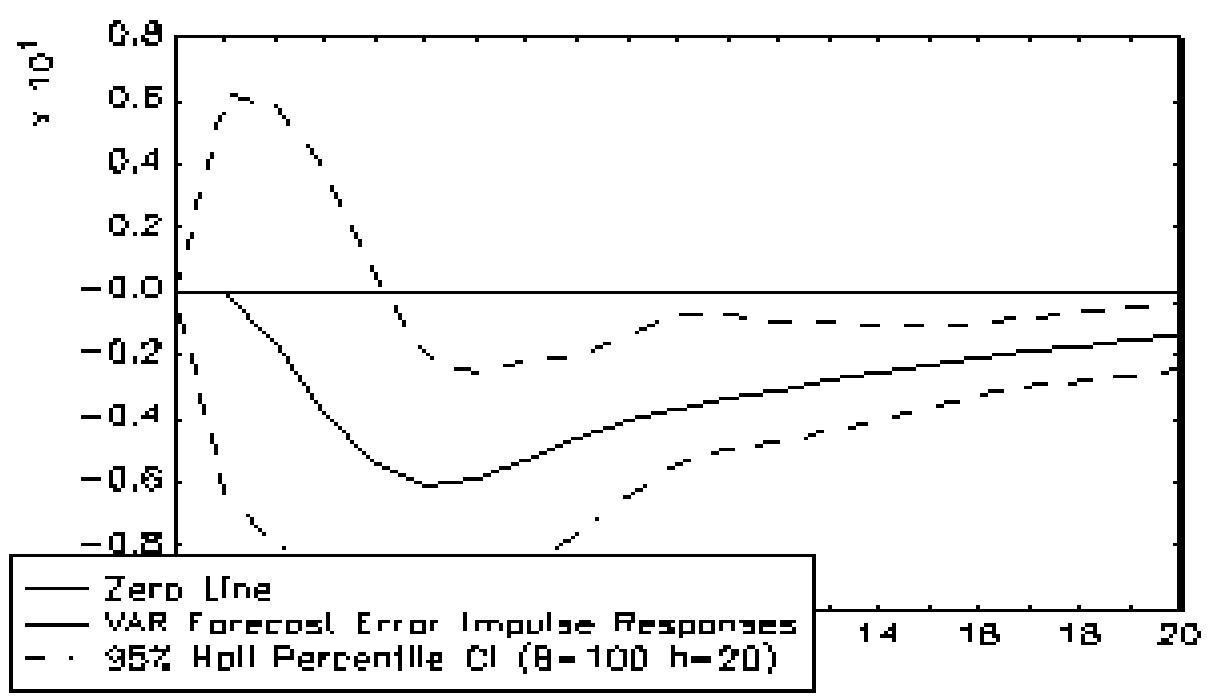




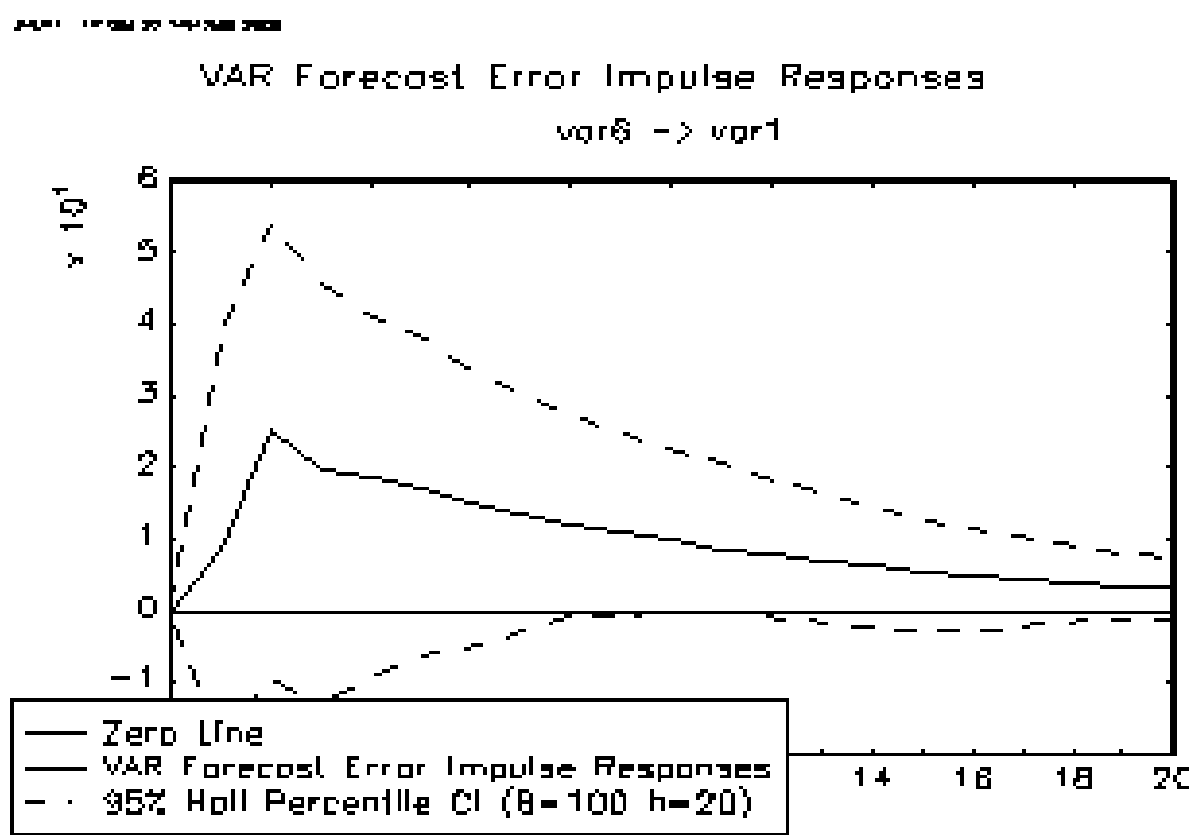

Figure 3

Impulse Responses for the USD/DEM Real Exchange Rates. The following variables are shown in the above graphs: Variable 1- real exchange rate, Variable 2- productivity, Variable 3- output

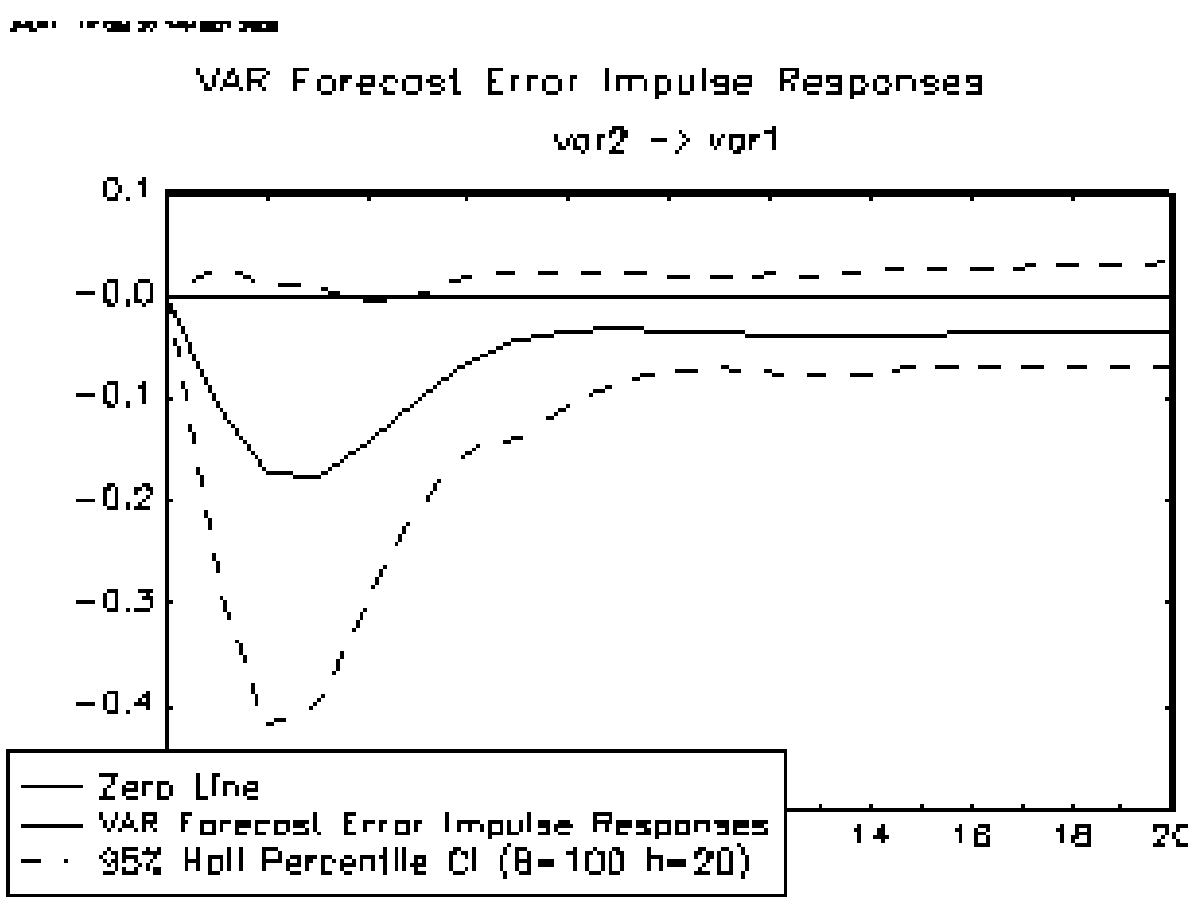




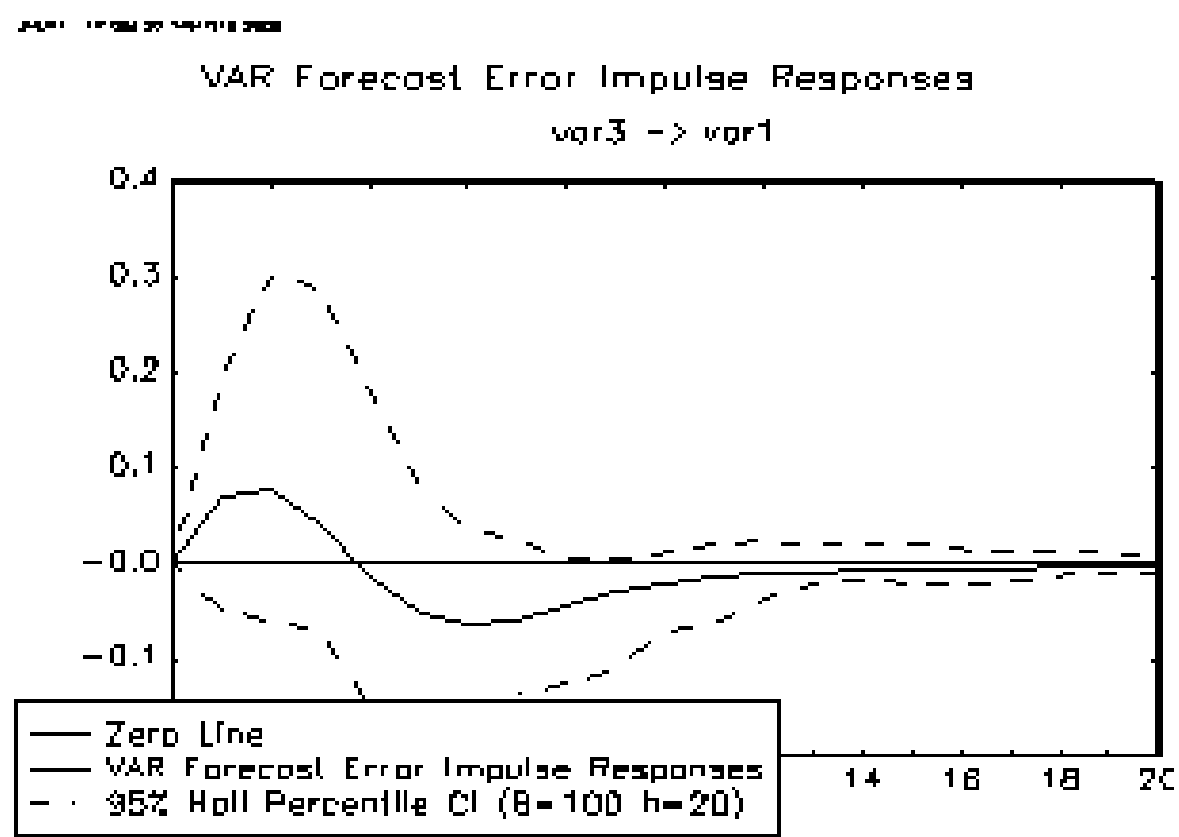

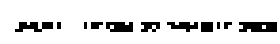

VAR Forecost Error Impulge Regponseg

vord -> vor 1

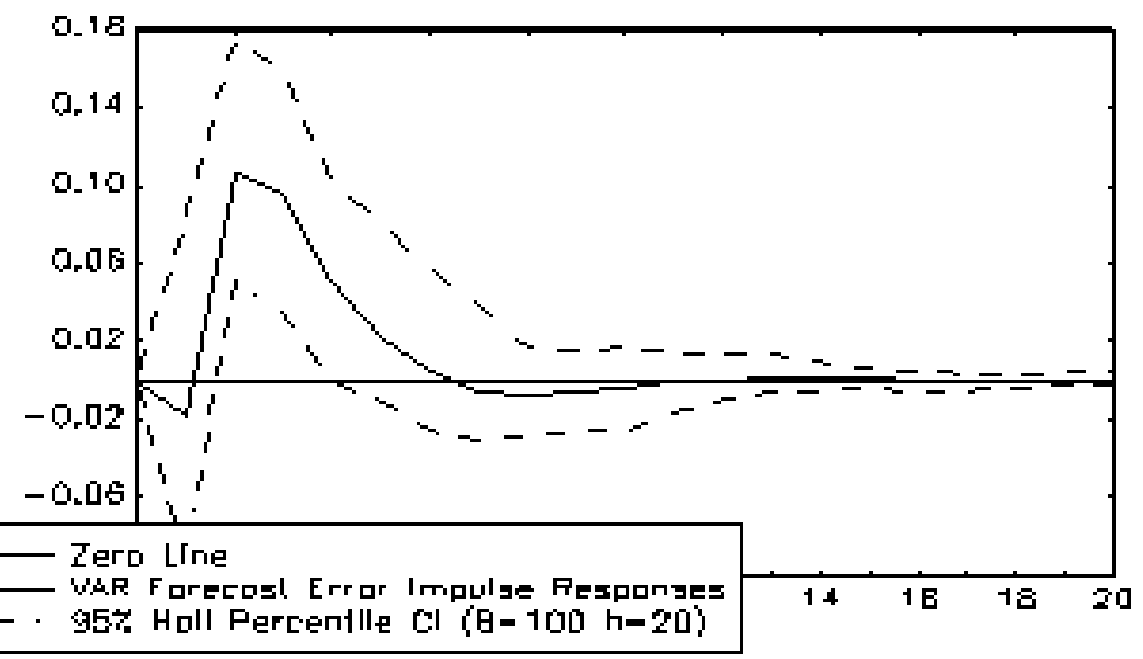


Figure 3

Impulse Responses for the USD/DEM Real Exchange Rates. The following variables are shown in the above graphs: Variable 1- real exchange rate, Variable 5- prices, and Variable 6- aggregate demand.
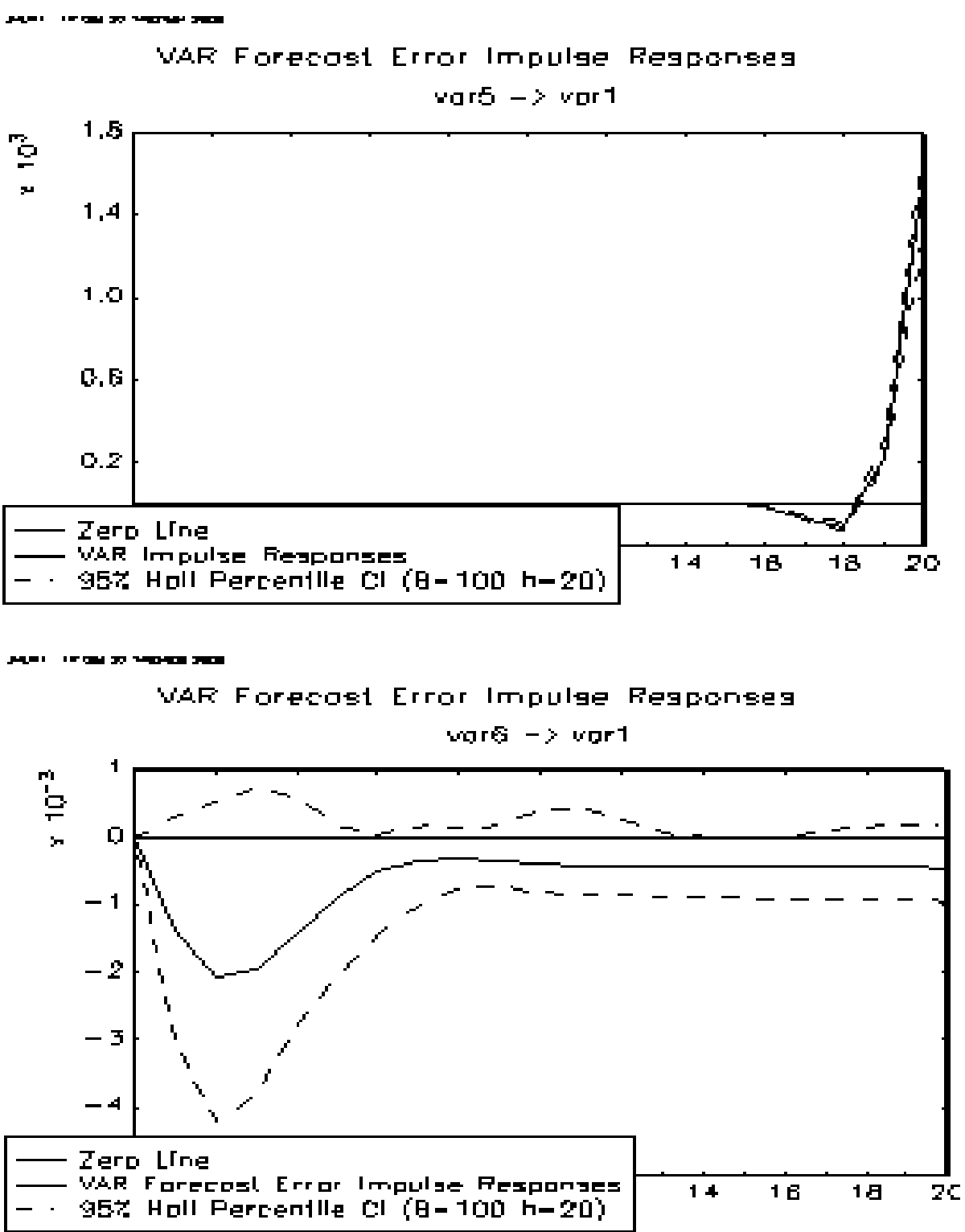
Figure 3

Impulse Responses for the GBP/USD Real Exchange Rates. The following variables are shown in the above graphs:

Variable 1- real exchange rate, Variable 2- productivity, Variable 3- output.

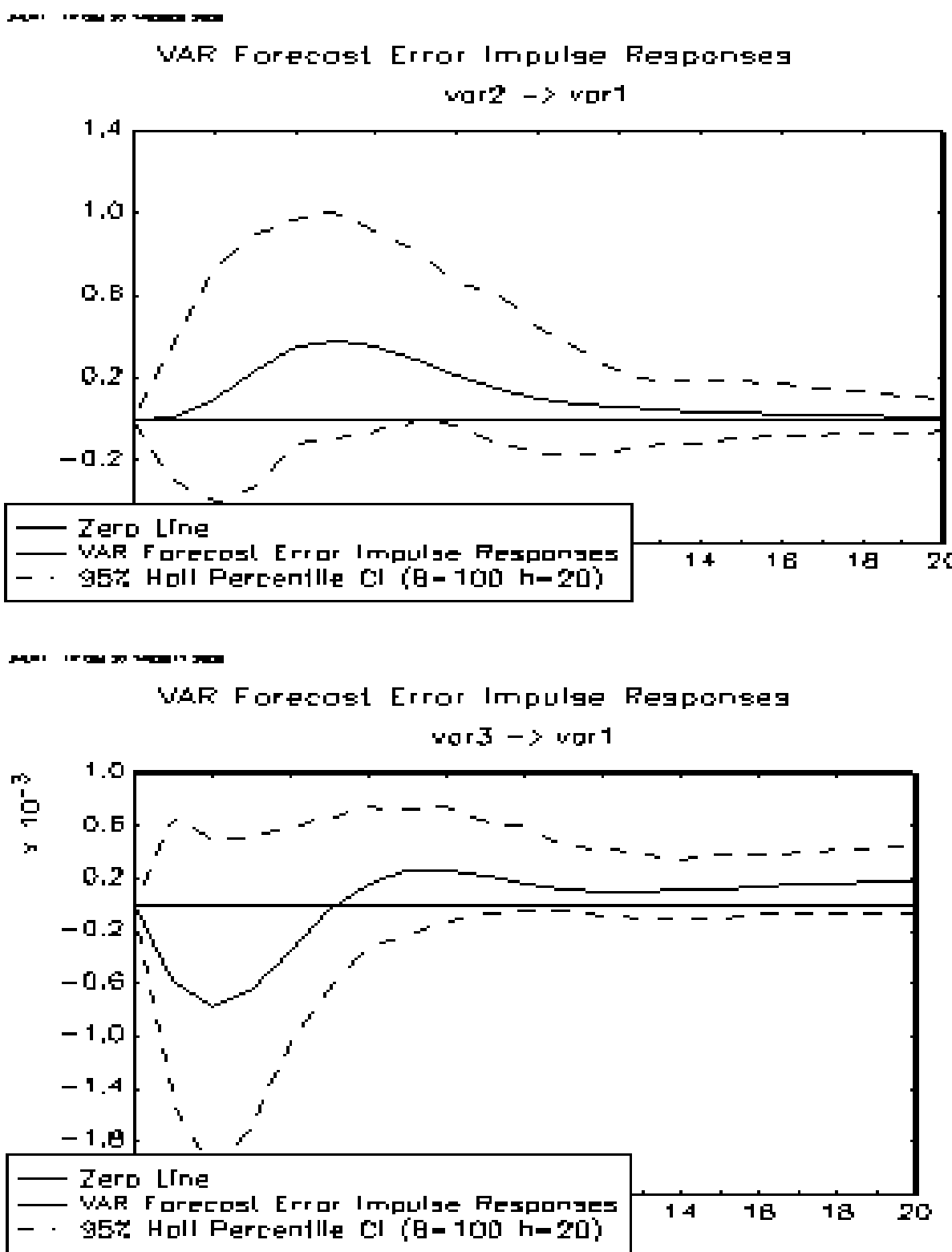




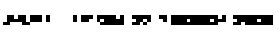

VAR Forecost Error Impulge Regponses

vor4 - vor 1

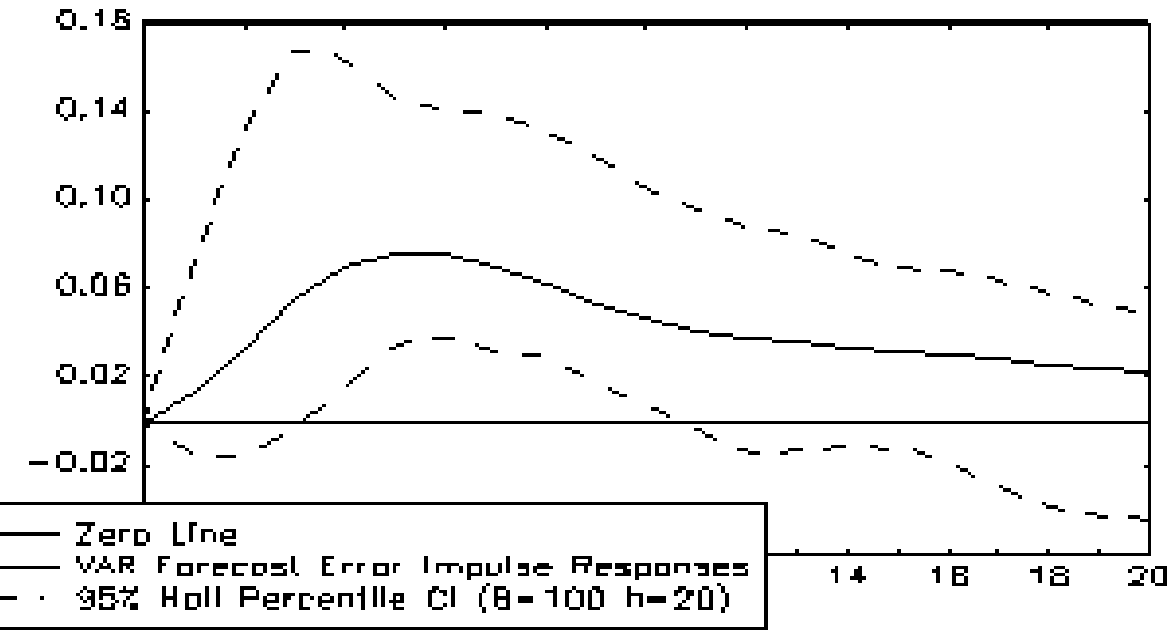


Figure 3

Impulse Responses for the GBP/USD Real Exchange Rates. The following variables are shown in the above graphs: Variable 1- real exchange rate, Variable 5- prices, and Variable 6- aggregate demand.
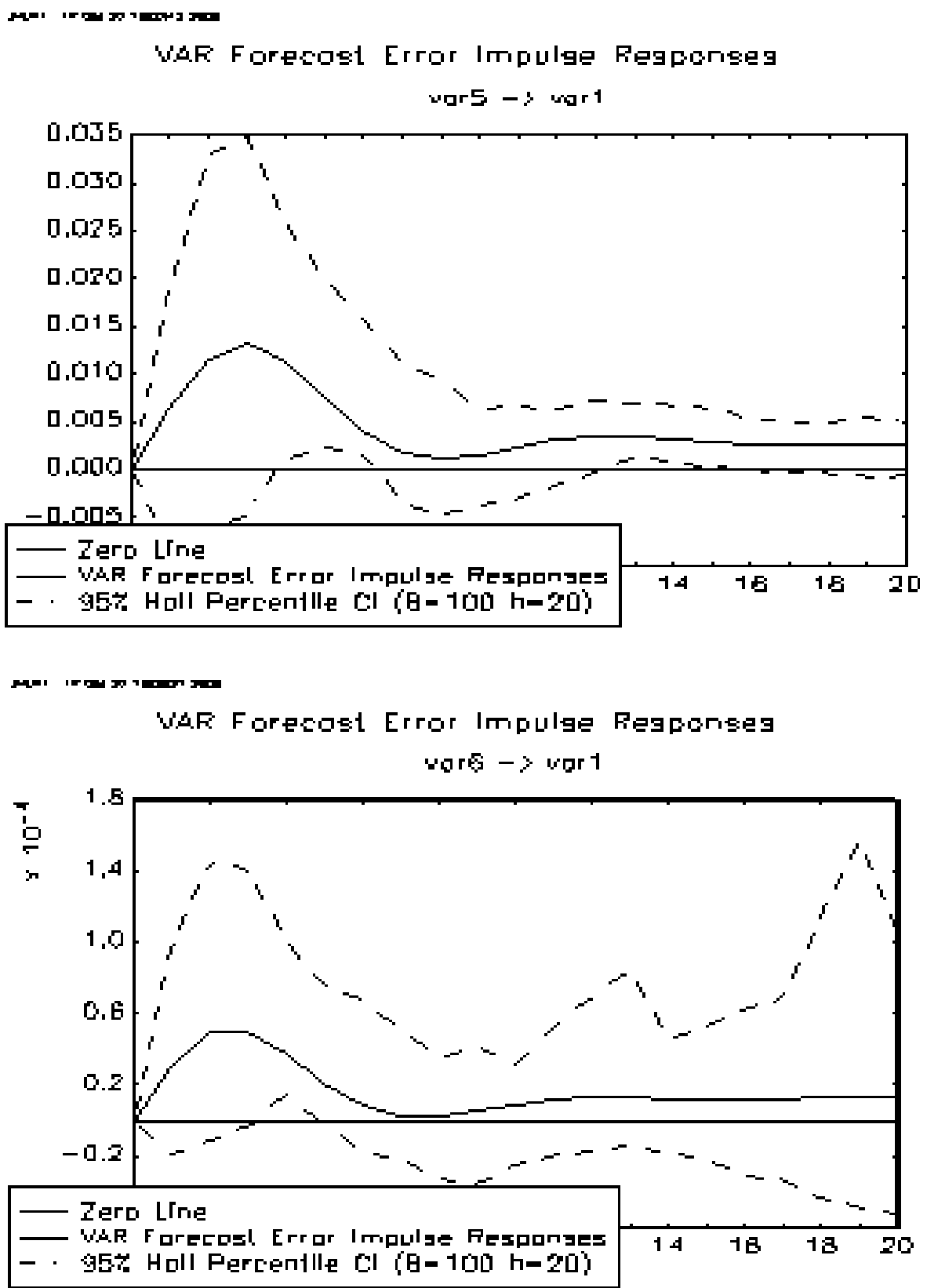
NOTES 